\title{
Carla Thies
}

\section{Kulturelle Vielfalt als Legitimitätselement der internationalen Gemeinschaft}

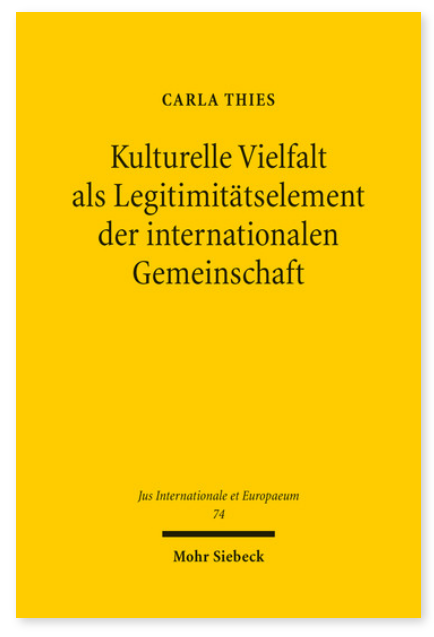

2013. XI, 419 Seiten. JusIntEu 74

SBN 978-3-16-152160-7

DOI 10.1628/978-3-16-152160-7

eBook PDF 104,00€

ISBN 978-3-16-151883-6

fadengeheftete Broschur $104,00 €$
Carla Thies untersucht die Funktion und Bedeutung des Begriffs der Legitimität im Bereich des Völkerrechts am Beispiel der Thematik kultureller Vielfalt. Mit dem Begriff der Legitimität wird rechtstheoretisch die Vorstellung verknüpft, dass das positive Völkerrecht von bestimmten, von ihm bereits vorausgesetzten Interessen und Grundprinzipien abhängig ist. Sie dienen aus der Legitimitätsperspektive als normative Grundlage der Staatengemeinschaft. Die Autorin klärt dabei die Frage, inwieweit sich mit der rechtlichen Instrumentierung kultureller Vielfalt auch der Topos kultureller Vielfalt auf der Grundlage von drei völkerrechtlichen Säulen, dem Selbstbestimmungsrecht der Völker, den kulturellen Rechten und dem Recht auf Entwicklung zu einem selbständigen, völkerrechtlich inkorporierten Legitimitätselement entwickelt hat.

Carla Thies Geboren 1980; Studium der Rechtswissenschaften in Passau, München und Leuven; 2006-12 wissenschaftliche Mitarbeiterin am Lehrstuhl für Öffentliches Recht, Völker- und Europarecht der Ludwig-Maximilians-Universität München; 2009-11 Referendariat in München, Wahlstation in Washington D.C.; seit März 2012 Rechtsanwältin in München.
Jetzt bestellen:

https://mohrsiebeck.com/buch/kulturelle-vielfalt-als-legitimitaetselement-der-internationalen-gemeinschaft-9783161521607? no_cache=1

order@mohrsiebeck.com

Telefon: +49 (0)7071-923-17

Telefax: $+49(0) 7071-51104$ 